\title{
Educación médica basada en resultados. I. Principios básicos y ventajas
}

\author{
A. Wojtczak
}

En un número de la revista Medical Teacher [1] dedicado a la educación basada en los resultados (EBR, del inglés, outcome-based education-OBE-) se describe el gran progreso que se ha producido en la introducción de este modelo en un número creciente de facultades de medicina de diferentes países. El autor de estas líneas es uno de los activos defensores de este modelo tan demandado e innovador que ha supuesto un profundo cambio en la educación médica, así que permítanme compartir con ustedes algunas reflexiones sobre este fascinante enfoque.

Sin olvidar a algunos educadores que en el pasado presentaron este punto de vista, no hay duda de que el mérito de haber señalado el camino de la educación médica basada en los resultados corresponde a Ron Harden [2], quien ya en 1999 formuló sus principios básicos. La esencia de la $\mathrm{EBR} / \mathrm{OBE}$ radica en que la educación o la formación vienen definidas por una serie de resultados del aprendizaje que indican las competencias profesionales que se deberían poseer en el momento de la evaluación.

Los resultados del aprendizaje deberían establecer claramente los conocimientos que se espera que los estudiantes aprendan y aquello que se espera que sepan hacer. La EBR/OBE refleja el paso de un modelo en que se pone énfasis en el proceso, donde lo que prima son los métodos de enseñanza y de aprendizaje a otro en el se pone el énfasis en la calidad del producto, en las competencias que se espera que hayan adquirido los graduados o los médicos. En el modelo tradicional, los programas se definen en función de su duración, sus contenidos o los métodos de enseñanza, pero no especifica qué habilidades o conocimientos deben adquirir los estudiantes al lo largo de estos programas. Esto cuestiona la validez de lo que enseñamos y cómo lo enseñamos. Es importante añadir que el modelo de la EBR/OBE no resuelve por sí mismo las disputas sobre los contenidos y sobre aquello que debe incluirse en un currículo nuclear, pero sin embargo indica qué aspectos hay que tener en cuenta cuando planificamos el contenido del currículo y los métodos de enseñanza. La EBR/OBE también permite hacer un seguimiento del progreso del estudiante a lo largo de las diferentes etapas del currículo y también en la planificación del continuum entre la formación pregraduada y posgraduada. Los métodos de evaluación adoptados deben reflejar los resultados de aprendizaje acordados y deberían informar sobre si un estudiante ha adquirido o no los resultados establecidos. Estos métodos pueden incluir exámenes escritos como los de respuesta múltiple, los denominados extended matching items, métodos de evaluación de la competencia clínica como las ECOE, la observación estructurada y el portafolio. Los métodos deberían ser capaces de evaluar también competencias de los estudiantes de medicina en áreas que tradicionalmente no se han tenido en cuenta como el profesionalismo, el aprendizaje a lo largo de toda la vida, la capacidad de autocrítica y de autoevaluación y el crecimiento personal, el razonamiento moral y la ética médica. En el proceso de evaluación, la mayor responsabilidad recae en los estudiantes que deben demostrar que han adquirido las competencias necesarias. Un elemento clave en el proceso de evaluación es el feedback que debe darse al estudiante en su progreso en relación con cada uno de los resultados.

Después de haber completado la evaluación de los requerimientos médicos esenciales mínimos globales (global minimum essential requirements -GMER-), en ocho universidades médicas líderes en China, no tengo dudas de que ésta es la forma de 
poner la educación médica en el camino correcto y acabar con las discusiones interminables acerca del número de horas y la secuencia de las disciplinas que se deben incluir en los currículos médicos y enfocarlos a las competencias de los graduados. Es la mejor evidencia de la calidad de los logros educativos de las facultades de medicina. Al leer con profundo interés y placer este interesantísimo número de la revista Medical Teacher, estoy cada vez más convencido de que la educación médica basada en los resultados es la respuesta correcta para hacer frente a los retos de la educación médica, y puedo decir con satisfacción que la EBR/OBE ha empezado a ser aplicada cada vez más profunda y extensamente en los programas educativos de las facultades de medicina en diferentes partes del mundo.

\section{Outcome-based medical education. I. Basic principles and advantages}

The issue of Medical Teacher [1] them to the outcomebased education (OBE) presents a huge progress made in an introduction of this model in increasing number of medical schools and countries. Being one of the active proponents of this very demanding and innovative process, deeply changing medical education, provoked me to share with you some thoughts on this fascinating approach.

There is no doubt, even if we invoke some educators who were in past presenting this idea, that the merit of path tracer of the outcome-base medical education goes to Ron Harden [2], who already in 1999 formulated its basic principles. The essence of $O B E$ is that the education or training is defined by set of learning outcomes indicating the professional competences that should be possessed by time of assessment. They should clearly state what knowledge students are expected to learn and what are expected to do. The OBE reflects a switch from an emphasis on process, where what matters are the teaching and learning methods, to quality of product, where the emphasis is on the competences that are expected from graduates or doctors. In traditional approach courses are defined in terms of their duration, specification of content and the forms of teaching, and is not said what skills or knowledge students should acquire from given course. It questions the validity of many issues we teach and ways how we teach. It is important to add that the OBE model does not itself resolve disputes about content and what should be included in a core curriculum, but it indicates, however, what issues need to be addressed when planning the content of curriculum and teaching methods. The OBE also permits on the monitoring of a student's progress through the different phases of the curriculum and also in the planning for a continuum between undergraduate education and postgraduate education. Adopted assessment methods must reflect the agreed learning outcomes and should inform as to whether a student has or has not achieved the stated outcomes. They can include written assessments such as multiple choice questions, extended matching items, performance assessments such as the OSCE, structured observations and portfolios. They should be able to assess medical students' competencies in areas that have not traditionally been taken in account such as professionalism, life-long learning, self-awareness and personal growth, moral reasoning and clinical ethics. In an assessment process, the greater responsibility is given to the students to demonstrate that they have achieved the necessary outcomes. A key element in the assessment process is the feedback of information that must be provided to the student as to their level of achievement in relation to each of the outcomes.

After completing, the assessment of the global medical essential requirements (GMER) in 8 leading medical universities in China, I have no doubt that it is the most suitable way of "putting medical education on the right track" and to break the never ending discussions about number of hours and sequence of various discipline to be included in medical curricula, and focus on the graduates' competences. It is a best evidence of quality of medical school educational achievements. When reading with a deep interest and pleasure this most interesting volume, of Medical Teacher, I am even more convinced that the outcome-based medical education is a right answer to present challenges of medical education and with satisfaction I must say that OBE has started to be rooted deeper and broader in educational programs of medical schools in different parts of the world.

\section{Bibliografía}

1. Harden RM. Outcome-based education: the future is today. Medical Teacher 2007; 29: 625-9.

2 Director of Education for the International Virtual Medical School (IVIMEDS), General Secretary of the Association for Medical Education in Europe (AMEE) and Editor of Medical Teacher; formerly Director of the Centre for Medical Education, Postgraduate Dean and Teaching Dean at University of Dundee, UK. 